\title{
Preventing the Tragedy of Suicide Among Indigenous People in Canada: Physician Advocacy Through the Training Pipeline and Beyond
}

\author{
Max Deschner, BA ${ }^{1}$, Emilie Glanz, BSc ${ }^{1}$ \\ ${ }^{1}$ Faculty of Medicine, University of Ottawa
}

A BSTRACT

For decades, Canada's Indigenous populations have experienced high rates of suicide relative to the general population. This commentary suggests that suicide among Indigenous people cannot be explained solely through the causal effects of downstream determinants of health; upstream health determinants such as Canada's colonial past and cultural continuity are equally, if not more, instructive in understanding the tragedy that is taking place in many Indigenous communities across Canada. Medical trainees and physicians can contribute to improvements in Indigenous health by advocating for culturally safe healthcare access and research, as well as Indigenous-oriented medical training.

\section{RÉ S U Ḿ}

Pendant des décennies, les populations autochtones au Canada ont connu des taux élevés de suicide comparativement à la population générale. Ce commentaire suggère que le suicide chez les personnes autochtones ne peut être expliqué uniquement par les effets causaux des déterminants de la santé " en aval "; les déterminants de la santé " en amont ", tels le passé colonial du Canada et la continuité culturelle, sont tout aussi, sinon plus importants pour comprendre la tragédie se déroulant dans plusieurs communautés autochtones à travers le Canada. Les médecins et étudiants en médecine peuvent contribuer à l'amélioration de la santé autochtone en plaidant pour de la recherche et un accès aux soins de santé qui sont culturellement sécuritaires, et pour des formations médicales axées sur la santé autochtone.

\section{INTRODUCTION}

In April 2016, Attawapiskat First Nation of Northern Ontario declared a state of emergency in response to a spate of suicide attempts since the fall of 2015. Just one month earlier, Pimicikamak Cree Nation (Cross Lake) of Northern Manitoba also declared a state of emergency following the suicides of six community members since December 12, 2015. Both tragedies have brought renewed - and much needed - attention to what the National Chief of the Assembly of First Nations, Perry Bellegarde, has characterized as a suicide epidemic experienced by Indigenous communities across Canada [1]. Despite headlines that might suggest otherwise, this epidemic is nothing new. For decades, Canada's Indigenous people - the First Nations, Métis and Inuit, each having unique traditional territories, cultural practices, languages and histories - have experienced high rates of suicide relative to the general population. The 1998 Royal Commission of Aboriginal Peoples noted that the suicide rate of Indigenous Canadians was three times that of non-Indigenous people [2]. The suicide rate among Indigenous youth is particularly alarming, accounting for more than one-third of mortality [3]. Recent data suggests First Nations youth commit suicide five to six times more often than non-Indigenous youth [4]. Inuit youth experience a suicide rate 11 times the national average; this is among the highest rates in the world [4]. More generally, $29 \%$ of Inuit people have attempted suicide at least once in their lifetime [5].

Keywords: Indigenous Population; Health Services, Indigenous; Patient Advocacy; Education; Medical
Suicide is the result of a complex interplay of personal, community, social, political and historical realities [3]. It is therefore important to understand suicide within the context of both individual risk factors and the broader psychosocial health of a population [3]. Suicide is a tragic response by too many Indigenous Canadians - particularly youth - to social, economic and political inequities, as well as the seemingly ineluctable effects of intergenerational trauma caused by colonial policies. This commentary argues that suicide among Indigenous people is a tragedy that cannot be explained solely through the causal effects of downstream determinants of health. Upstream health determinants such as Canada's colonial past and cultural continuity are equally, if not more, instructive in understanding what is taking place in many Indigenous communities across Canada. Physicians and medical trainees can contribute to improvements in Indigenous health by advocating for culturally safe healthcare access and research, as well as Indigenous-oriented medical training.

\section{DOWNSTREAM DETERMINANTS OF HEALTH: INDIVIDUAL RISK FACTORS AND PROTECTIVE FACTORS}

The immediate causes of suicide are attributable to the effects of downstream determinants of health. These determinants include individual-level risk factors and protective factors that influence one's health outcomes such as physical environments, developmental experiences, alcohol and substance abuse, socio- 
economic status, education and access to healthcare. Poor mental health is a leading individual risk factor for suicide. Suicide by adolescents and young adults often occurs in the setting of affective disorders such as major depressive disorder and bipolar disorder [3]. Individuals are particularly vulnerable to suicide in cases of substance abuse - most notably alcohol use [6]. Indigenous youth are two to six times more likely to suffer from alcohol-related problems than non-Indigenous Canadians [7]. Compared to their non-Indigenous counterparts, Indigenous youth are more likely to use illegal drugs and to begin using these substances at an earlier age [7]. Other risk factors include suicide of family members or friends, previous physical or sexual abuse, social isolation, poverty and unemployment [3]. Suicide rates are highest in Indigenous adolescents who have physical illnesses, have previously attempted suicide, have a history with the criminal justice system or have lived in multiple home placements [3]. On the contrary, individual protective factors preventing suicide include good physical and mental health, self-esteem, future orientation, peer support and coping skills $[3,8]$.

Individual downstream health determinants are important to consider when identifying Indigenous people at risk of committing suicide, but they are not enough to single-handedly explain high rates of suicide among Indigenous people. While non-Indigenous populations also have many of the same individual risk factors for suicide, these risk factors are more prevalent among Indigenous people as a result of broader social and historical pressures - namely the legacies of colonialism and acculturation policies imposed by Canadian political and social institutions $[3,9]$.

\section{UPSTREAM DETERMINANTS OF HEALTH: INDIGENOUS HEALTH AS A NEXUS OF HISTORY, POLITICS AND CULTURE}

In trying to understand high levels of suicide among Indigenous people, it is important to explore the role of historical, political and cultural factors on overall health. Upstream health determinants are the overlying influences that largely determine the health status of a particular population. Upstream determinants set the context within which downstream determinants can be understood. From an Indigenous health perspective, upstream determinants include Canada's colonial history, past and present government policies such as the residential school system, selfdetermination and cultural continuity $[10,11]$. The World Health Organization contends that the colonization of Indigenous peoples is a fundamental health determinant [10]. In Canada, colonization led to "cultural genocide" of Indigenous people through institutional racism, land dispossession, family separations, residential schools and the widespread intergenerational trauma effected by these systems.

The cultural genocide of Indigenous people is linked to the dis- ease burden and higher rates of violence and early death faced by these individuals $[3,11,12]$. Today, Indigenous people have a higher risk of committing suicide relative to non-Indigenous people due to acculturation stress and cultural marginalization [3]. Many individuals struggle to acquire Indigenous values, while failing to connect with the dominant values of Western society. Indigenous people also experience higher rates of chronic disease, fatal accidents and overall mortality compared to non-Indigenous populations [13]. Indigenous people are more likely to report respiratory problems and unhealthy behaviours like smoking and drinking; they also suffer from higher rates of obesity and diabetes and have less access to safe, secure and nutritious food [13]. While direct causal links to suicidality and poor health outcomes are challenging to confirm, it is important to outline the potential multi-generational impact of upstream determinants such as the residential school system on the health status of Canada's Indigenous population today.

Cultural continuity is an important upstream determinant of Indigenous health. It is defined as a community's sense of its own historical continuity and identity, and has traditionally been solidified through intergenerational bonds forged by close families and vibrant traditions $[3,14]$. In many Indigenous communities, cultural continuity has been challenged by government policies such as the residential school and child welfare systems. These policies have interrupted the transmission of culture - a practice that has sustained the threads of healthy Indigenous societies for thousands of years [3]. Today, residential school survivors and their families are at high risk of experiencing depression, suicidal ideation and suicide attempts [3]. Conversely, low rates of suicide within certain First Nations communities in British Columbia have been linked to conditions that promote cultural continuity such as land title, self-government and control over health, education and social programs [14]. Communities with three or more protective factors experienced suicide rates of approximately $2 / 100,000$; the numbers were much grimmer in the absence of protective factors: nearly 138/100,000 [14].

\section{CHAMPIONING INDIGENOUS HEALTH AND WELLBEING: WHAT CAN PHYSICIANS AND MEDICAL TRAINEES DO?}

In helping to improve Indigenous health outcomes, physicians and medical trainees can lead the development of preventionbased solutions to the epidemic of suicide among Indigenous people. The complexity of this tragedy means that a broad scope of stakeholders must develop tangible prevention strategies at both the policy and community levels. There is a pressing need for more investments that will enable young people to access critical social services, as well as meaningful education, employment and recreation opportunities. As front-line care providers, physicians bear witness to the health challenges and spirited resiliency of Indigenous people. Physicians are health advocates 
and therefore share a responsibility to champion the causes of marginalized populations in both urban and rural settings [15]. Advocacy means fighting for appropriate and timely access to culturally safe healthcare services. In light of historical oppression, many Indigenous people approach Western medicine with understandable caution. Cultural safety aims to mediate Indigenous peoples' interactions with healthcare and government services by acknowledging inherent inequities and power differentials. Culturally safe healthcare provision recognizes the social, political and historical context of accessing care and ensures that Indigenous people define safe healthcare on their own terms [16]. Physicians must recognize that health and wellbeing are equal parts spiritual, mental, physical and emotional; this is demonstrated in the four quadrants of the medicine wheel [17]. In acknowledging the importance of the wheel, physicians can better respect traditional beliefs and healing practices, as well as refrain from enforcing their own values on Indigenous patients. While not all physicians will promote cultural safety on a system-wide basis, they can deliver healthcare using this approach to ensure their own interactions with Indigenous patients are culturally appropriate and supportive.

Indigenous communities need to see more investments in evidence-based suicide prevention and treatment strategies. For instance, flying patients with suicidal ideation or previous suicide attempts from remote communities to distant tertiary care centres to receive short courses of mental health treatment is not a long-term solution. Physicians can contribute to the development and implementation of evidence-based strategies that emphasize the role of the upstream determinants of health in improving community health and wellbeing. Furthermore, health research should be rooted in culturally safe ethical guidelines and should foster collaboration with Indigenous groups. Ownership, Control, Access and Possession (OCAP) is an example of a research model in which Indigenous people have direct ownership and control over research knowledge about their communities. OCAP is inherently linked to the self-determination and cultural preservation of Indigenous people [18]. Community-based participatory research is another model in which studies are undertaken alongside research subjects with the end goal of promoting equitable social change [19]. At the policy level, Canada requires stronger research infrastructure to ensure important evidence is disseminated and translated into action. The creation of the National Collaborating Centre for Aboriginal Health by the Government of Canada in 2005 was a step in the right direction. This organization collaborates with researchers and clinicians to translate knowledge on what works into action. Unfortunately, other important Indigenous health organizations that espouse Indigenous research ethics, including the Aboriginal Healing Foundation and the National Aboriginal Health Organization, have seen their funding terminated in recent years [11].
Cultural safety and consensus are Indigenous values inherent to the CanMEDS "Medical Expert" role [15]. Indigenous medical education is improving across Canada, however most students are still not exposed to Indigenous health topics over the long term. At the medical school level, physicians and students can advocate for more training of Indigenous healthcare workers. Indigenous healthcare workers are often best prepared to provide culturally safe healthcare to other Indigenous people [20]. Indigenous Canadians are sorely underrepresented in Canada's healthcare workforce. They make up approximately $4.3 \%$ of the national population, but only $0.25 \%$ of its physicians $[21,22]$. The Canadian Federation of Medical Students (CFMS) has responded to this problem by endorsing several strategies to improve medical trainees' exposure to Indigenous health issues. Among these, the CFMS recommends that medical schools increase the recruitment of Indigenous students through a targeted, culturally safe, and comprehensive pipeline approach; implement mandatory, culturally safe Indigenous health curricula and experiential learning into medical training; and increase accountability to local Indigenous communities through meaningful engagement [23]. By actualizing these practices, Canadian medical schools will train more physicians - both Indigenous and non-Indigenous - who respect Indigenous ways of knowing and who actively promote cultural safety in clinical practice and research.

\section{CONCLUSION}

High suicide rates in many Canadian Indigenous communities are an indicator of poor health and social outcomes rooted in upstream determinants of health. While suicide among Indigenous peoples are a result of the interplay between downstream health determinants that manifest as individual risk factors and protective factors, it is important to explore the links between suicide and historical inequalities that have negatively affected the broader health status of Indigenous people. Physicians and medical trainees have a responsibility to advocate for improved Indigenous health and wellbeing by recognizing the causal effects of both downstream and upstream determinants of health and by taking action at both ends of the stream.

\section{REFERENCES}

1. Puxley C. AFN top chief Perry Bellegarde calls for national suicide strategy. [Internet]. Location. The Globe and Mail. [updated: 2016 Mar 11; cited 2016 Mar 12]. Available from: http://www.theglobeandmail.com/news/national/ afn-national-chief-perry-bellegarde-calls-for-national-suicide-strategy/article29187806/.

2. Aboriginal Affairs and Northern Development Canada. Royal Commission on Aboriginal Peoples [Internet]. Ottawa (ON): Government of Canada; 2011 [updated: 2016 Jan 12; cited 2016 Feb 20]. Available from: http:// www.aadnc-aandc.gc.ca/eng/1307458586498/1307458751962.

3. Kirmayer LJ, Brass GM, Holton T, Paul K, Simpson C, Tait C. Suicide among Aboriginal people in Canada [Internet]. Ottawa (ON): The Aboriginal Healing Foundation; 2007 [cited 2016 Feb 20]. Available from: http://www.ahf.ca/ downloads/suicide.pdf.

4. Health Canada. First Nations and Inuit health: mental health and wellness 


\section{Commentary}

[Internet]. Ottawa (ON): Health Canada; 2015 Jan 27 [cited 2016 Feb 22]. Available from: http://www.hc-sc.gc.ca/fniah-spnia/promotion/mental/ index-eng.php.

5. Galloway T, Saudny H. Inuit health survey 2007-2008: Nunavut community and personal wellness [Internet]. Montreal (QC): McGill University Centre for Indigenous Peoples' Nutrition and Environment; 2012 [cited 2016 Feb 15]. Available from: http://www.inuitknowledge.ca/sites/naasautit/files/at tachments/2008CommunityPersonalWellness-nunavut.pdf.

6. Turecki G. Dissecting the suicide phenotype: The role of impulsive-aggressive behaviours. J Psychiatry Neurosci. 2005;30(6): 398-408.

7. Currie J. Best Practices: Treatment and Rehabilitation for Youth with Substance Abuse Problems [Internet]. Ottawa (ON): Minister of Public Works and Government Services; 2001 [cited 2016 Feb 25]. Available from: http:// www.hc-sc.gc.ca/hc-ps/pubs/adp-apd/youth-jeunes/index-eng.php.

8. Pharris MD, Resnick MD, Blum RW. Protecting Against Hopelessness and Suicidality in Sexually Abused American Indian Adolescents. J Adolesc Health. 1997; 21(6): 400-406.

9. Borowsky IW, Resnick MD, Ireland M, Blum RW. Suicide Attempts Among American Indian and Alaska Native Youth: Risk and Protective Factors. Arch Pediatr Adolesc Med. 1999; 153(6): 573-580.

10. World Health Organization Commission on Social Determinants of Health. Social determinants and Indigenous health: the international experience and its policy implications [Internet]. Geneva: World Health Commission; 2007 [cited 2016 Feb 22]. Available from: http://www.who.int/social_determinants/resources/indigenous_health_adelaide_report_07.pdf.

11. Truth and Reconciliation Commission. Honouring the Truth, Reconciling for the Future: Summary of the Final Report of the Truth and Reconciliation Commission of Canada [Internet]. Winnipeg (MB): Truth and Reconciliation Commission; 2015 [cited 2016 Feb 22]. Available from: http://www.trc.ca/ websites/trcinstitution/File/2015/Exec_Summary_2015_06_25_web_o. pdf.

12. Reading C, Wien F. Health Inequalities and Social Determinants of Aboriginal Peoples' Health [Internet]. Prince George (BC): National Collaborating Centre for Aboriginal Health; 2013 [cited 2016 Feb 20]. Available from: http:// www.nccah-cnsa.ca/Publications/Lists/Publications/Attachments/46/ health_inequalities_EN_web.pdf.

13. Statistics Canada. Select Health Indicators of First Nations People Living Off Reserve, Métis and Inuit [Internet]. Ottawa (ON): Statistics Canada; 2013 [cited 2016 March 10]. Available from: http://www.statcan.gc.ca/pub/82624-x/2013001/article/11763-eng.htm.

14. Chandler MJ, Lalonde C. Cultural Continuity as a Hedge Against Suicide in Canada's First Nations. Transcult Psychiatry. 1998; 35(2): 191-219.

15. Royal College of Physicians and Surgeons of Canada. CanMEDS [Internet]. Ottawa (ON): Royal College of Physicians and Surgeons of Canada; 2014 [cited 2016 Feb 20]. Available from: http://www.royalcollege.ca/portal/page/ portal/rc/canmeds.

16. IPAC-AFMC. Summary of Admissions and Support Programs for Indigenous Students at Canadian Faculties of Medicine [Internet]. Indigenous Physicians Association of Canada and Association of Faculties of Medicine of Canada; 2008 [cited 2016 Feb 20]. Available from: https://www.afmc.ca/ pdf/IPAC-AFMC_Summary_of_Admissions_\&_Support_Programs_Eng.pdf.

17. Macauley A. Improving Aboriginal Health: How Can Health Care Professionals Contribute? Can Fam Physician. 2009; 55(4): 334-336.

18. First Nations Information Governance Centre. The First Nations Principles of OCAP ${ }^{\circledR}$ [Internet]. Ottawa (ON): First Nations Information Governance Centre; 2016 [cited 2016 Feb 28]. Available from: http://fnigc.ca/ocap.html.

19. Participatory Research at McGill. PRAM [Internet]. Montreal (QC): McGill University; 2016 [cited 2016 Feb 20]. Available from: http://pram.mcgill.ca/.

20. Canadian Medical Schools Struggle to Recruit Aboriginal Students. Healthy Debate [Internet]. 2013 May 2 [cited 2016 Feb 27]. Available from: http:// healthydebate.ca/2013/05/topic/quality/recruitment-of-aboriginal-healthcare-workers.

21. Statistics Canada. Aboriginal Peoples in Canada: First Nations People, Métis and Inuit [Internet]. Ottawa (ON): Statistics Canada; 2015 [cited 2016 Feb 20]. Available from: https://www12.statcan.gc.ca/nhs-enm/2011/as-sa/99011-x/99-011-x2011001-eng.cfm.

22. Anderson M, Lavallee B. The Development of The First Nations, Inuit and Métis Medical Workforce [Internet]. Med J Aust. 2007 [cited 2016 Feb 20];186 (10):539-540. Available from: https://www.mja.com.au/journal/2007/186/10/development-first-nations-inuit-and-m-tis-medical-work- force.

23. Arkle M, Deschner M, Giroux R, Morrison R, Nelson D, Sauve A, Singh K. Indigenous peoples and health in Canadian medical education CFMS position paper [Internet]. Canadian Federation of Medical Students: 2015 [cited 2016 Feb 20]. Available from: http://www.cfms.org/attachments/ article/163/2015\%20Indigenous\%20Peoples\%20and\%20Health\%20in\%20 Medical\%20Education.pdf. 